\title{
Linkage analysis in adenomatous polyposis coli: the use of four closely linked DNA probes in $20 \mathrm{UK}$ families
}

\author{
M B Cachon-Gonzalez, J D A Delhanty, J Burn, K Tsioupra, M B Davis, J Attwood, \\ P Chapman
}

\begin{abstract}
Linkage analysis was carried out on 20 unselected UK families segregating for adenomatous polyposis coli (APC) using four closely linked DNA probes. Significant lod scores were obtained between $A P C$ and three markers: $\pi 227$ (D5S37) $\hat{\theta}=0 \cdot 16$; C11p11 (DSS71) $\hat{\theta}=0.10$; and YN5.48 (D5S81) $\hat{\theta}=0.00$. The fourth, ECB27 (D5S98), gave low lod scores. The APC gene showed linkage with at least one of the probes used in all families, which is in agreement with previous publications. Combined lod scores are now sufficiently high to allow the use of these probes in presymptomatic diagnosis. Despite the fact that $61 \%$ of persons at risk were informative for at least one DNA marker, only $15 \%$ were informative with flanking probes. One prenatal diagnosis was performed where the initial request had been for sterilisation.
\end{abstract}

Adenomatous polyposis coli (APC), also known as familial adenomatous polyposis, is a relatively common autosomal dominant condition. By the middle of the third decade of life most affected subjects have

Department of Genetics and Biometry, The Galton Laboratory, University College London, 4 Stephenson Way, London NW1 2HE.

M B Cachon-Gonzalez, J D A Delhanty, K Tsioupra

Regional Genetics Advisory Service, University of Newcastle upon Tyne.

J Burn, P Chapman

Institute of Neurology, The National Hospitals, London.

M B Davis

MRC Human Biochemical Genetics Unit, The Galton Laboratory, London.

J Attwood

Correspondence to Dr Delhanty.

Received for publication 19 March 1991.

Revised version accepted for publication 26 April 1991. developed about a thousand adenomatous polyps in the colon and rectum; one or more of these will inevitably progress to malignancy unless prophylactic colectomy is carried out. ${ }^{1}$ Extracolonic lesions include upper gastrointestinal tract adenomas, osteomas, sebaceous cysts, desmoid tumours, and, the important phenotypic marker, congenital hypertrophy of the retinal pigment epithelium (CHRPE). ${ }^{2}$ Colonic polyposis with the addition of the extracolonic lesions was formerly considered to constitute a distinct syndrome first described by Gardner. ${ }^{3}$

The gene for APC has been mapped to chromosome 5 , region q21-22, by close linkage to an anonymous DNA marker, C11p11 (D5S71). ${ }^{45}$ Linkage to the more informative probe, $\pi 227$ (D5S37) was subsequently reported ${ }^{6}$ and additional closely linked markers have since been isolated, the most important of which are ECB27 (D5S98), ${ }^{7}$ YN5.48 (D5S81), ${ }^{8}$ and, more recently, L5.62 and EF5.44. ${ }^{9}$ The evidence now available from genetic linkage studies suggests that Gardner's syndrome maps to the same region of chromosome 5 as $\mathrm{APC}^{8}$ and prevailing opinion is that the two cannot be clinically distinguished.

Linkage analysis with the probes C11p11, $\pi 227$, ECB27, YN5.48, EF5.44, and L5.62 has been reported in nine Scottish families by Dunlop et al. ${ }^{9}$ Recombinants were identified and together with other published data allowed a locus order of centromere- $\pi 227-C 11$ p11-ECB27-L5.62-APC-EF5.44YN5.48-telomere to be proposed. In their study no recombinants were found between the pairs of loci L5.62-ECB27, ECB27-C11p11, C11p11- $\pi 227$, EF5.44-L5.62, $A P C$-YN5.48, and $A P C$-E5.44. However, analysis of an informative Dutch pedigree showed that $\pi 227$ and YN5.48 closely flank the APC locus. ${ }^{10}$ It was suggested that this finding would allow prenatal and presymptomatic diagnosis of APC in the majority of families with more than $99.9 \%$ reliability. ${ }^{10}$

We report here our results of linkage analysis in 20 UK families using the four closely linked DNA markers, $\pi 227, \mathrm{C} 11 \mathrm{p} 11, \mathrm{ECB} 27$, and YN5.48. 


\section{Materials and methods}

The 20 families studied were from the Northern Region Polyposis Registry which was established in 1987. In these families, subjects with polyposis were identified from surgical records and the family members at risk were given periodic clinical examinations of the colon together with indirect ophthalmoscopy to look for the presence of CHRPEs, as described. ${ }^{112}$ To prevent the inclusion of false positives, bilateral CHRPEs with a total of eight or more typical lesions were considered to be definitively indicative of gene carrier status; where less than eight lesions were present the status was taken as unknown. Only families with at least one affected member expressing the CHRPE phenotype were scored in this way.

Where no information with regard to APC or CHRPE status was available an age dependent penetrance classification (described for the Dutch population ${ }^{6}$ ) was used, as follows: $6.0 \%$ for ages 0 to $12,32.5 \%$ for 13 to $17,66.5 \%$ for 18 to $22,89 \%$ for 23 to 27 years, and $98 \%$ for ages 28 and over. No distinction was made between families with respect to extracolonic features apart from CHRPEs.

High molecular weight DNA for restriction analysis was prepared from fresh or frozen blood by standard methods. ${ }^{13}$ Probe DNA clones used were as follows: $\pi 227$ (D5S37) ${ }^{14}$ as a 900 bp HindIII/EcoRI fragment in $\pi \mathrm{AN} 7$; C11p11 (D5S71) as a $3.6 \mathrm{~kb}$ $E c o$ RI fragment in pUC8; ECB27 $(D 5 S 98)^{7}$ as a $2.8 \mathrm{~kb}$ SalI fragment in phage lambda; and YN5.48 $(D 5 S 81)^{8}$ as a $2.4 \mathrm{~kb} T a q \mathrm{I}$ fragment cloned into the $A c c \mathrm{I}$ site of pUC18.

Purified DNA ( 5 to $10 \mu \mathrm{g}$ ) was digested with the appropriate restriction endonuclease ( $T a q I$ for the probe C11p11, BstXI, BclI, PstI, and MboI for $\pi 227, B g l \mathrm{II}$ for ECB27, and MspI for YN5.48), fractionated in 0.6 to $1.5 \%$ agarose gel, and transferred to Gene Screen Plus nylon filters (Dupont) as recommended by the manufacturers. Before prehybridisation the DNA was cross linked to the membrane by exposing it to $254 \mathrm{~nm}$ UV light for three minutes. Prehybridisation was carried out in $0.5 \%$ SDS, $10 \%$ dextran sulphate, and $0.8 \mathrm{~mol} / 1 \mathrm{NaCl}$ for 15 minutes to several hours at $65^{\circ} \mathrm{C}$. Probes were radiolabelled with $\alpha{ }^{32} \mathrm{P}-\mathrm{dCTP}\left(3000 \mathrm{Ci} \mathrm{mmol}^{-1}\right)$ by the random hexanucleotide primer method ${ }^{15}$ to a high specific activity, and hybridised to the filter at $65^{\circ} \mathrm{C}$ overnight in the presence of $10 \mu \mathrm{g} \mathrm{ml}^{-1}$ salmon sperm DNA. Filters were washed to a stringency of $2 \times$ SSC, $1 \%$ SDS and autoradiographed at $-70^{\circ} \mathrm{C}$ using Fuji RX-L $x$ ray film.

Linkage analysis was carried out using the LINKAGE group of programs, ${ }^{16}$ within the easier to use computer program LINKSYS. ${ }^{17}$ In family groups where recombination was apparent, paternity was checked with the use of at least three hypervariable DNA probes. ${ }^{18}$ Subjects for whom non-paternity was shown were excluded from the analysis.

\section{Results}

Twenty families segregating for the APC gene, comprising 180 typed subjects with 91 meioses, were screened for all the polymorphisms. Allele frequencies were determined in the unaffected spouses and are shown in table 1.

The results of the linkage analysis of APC to each of the four DNA markers, and of these to each other, are summarised in table 2 . The peak lod score $(\mathrm{Z} \max )$ and associated recombination fraction $(\hat{\theta})$, indicating the maximum likelihood of marker locations with respect to each other, was calculated using

Table 1 DNA probes recognising polymorphic loci on chromosome 5q: allele size, frequency in the spouse population, and number of informative families

\begin{tabular}{|c|c|c|c|c|c|c|}
\hline Probe & $\begin{array}{c}\text { Enzyme } \\
\text { recognising } \\
\text { polymorphism }\end{array}$ & Allele & Size (kb) & Frequency & $\begin{array}{c}\text { No of } \\
\text { chromosomes }\end{array}$ & $\begin{array}{l}\text { Informative } \\
\text { families (\%) }\end{array}$ \\
\hline YN5.48 & MspI & \multirow{7}{*}{$\begin{array}{l}\text { Y1 } \\
\text { Y2 } \\
\text { P1 } \\
\text { P2 } \\
\text { Z1 } \\
\text { Z2 } \\
\text { A1 } \\
\text { A2 } \\
\text { A3 } \\
\text { B1 } \\
\text { B2 } \\
\text { C1 } \\
\text { C2 } \\
\text { D1 } \\
\text { D2 }\end{array}$} & \multirow{7}{*}{$\begin{array}{c}9.0 \\
8.0 \\
11.9 \\
10.5 \\
4.4 \\
3.9 \\
8.0+1.2 \\
3.0 \\
1.8+1.2 \\
2.7 \\
2.3 \\
4.3 \\
3.0 \\
0.55 \\
0.45\end{array}$} & \multirow{7}{*}{$\begin{array}{l}0.51 \\
0.49 \\
0.39 \\
0.61 \\
0.20 \\
0.80 \\
0.16 \\
0.40 \\
0.44 \\
0.43 \\
0.57 \\
0.26 \\
0.74 \\
0.41 \\
0.59\end{array}$} & 68 & 55 \\
\hline ECB. $27^{7}$ & $B g l \mathrm{II}$ & & & & 70 & 65 \\
\hline C11p114 & TaqI & & & & 70 & \multirow[t]{3}{*}{50} \\
\hline$\pi 227^{14}$ & $B c l I$ & & & & 70 & \\
\hline & Bst XI & & & & 68 & \\
\hline & PstI & & & & 68 & \multirow{2}{*}{85} \\
\hline & $M b o I$ & & & & 66 & \\
\hline
\end{tabular}


Table 2 Pairwise lod scores for linkage

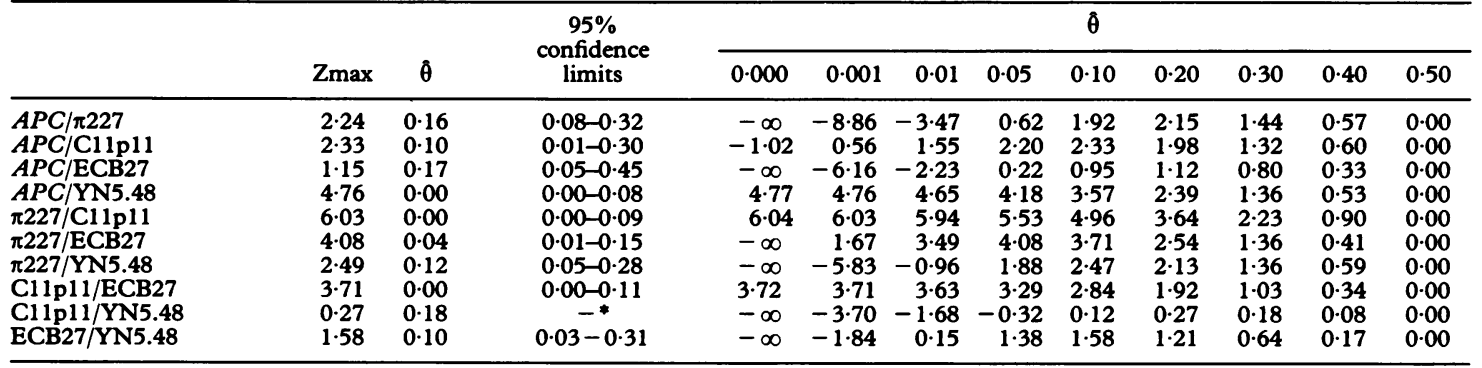

*Lod score is too small to calculate the confidence limits.

the LODSCORE program of LINKAGE. Lod scores for each pair of markers at different recombination fractions were calculated using the MLINK program of LINKAGE. The 1 lod unit of support was also determined, as indicated by Conneally et al. ${ }^{19}$ Only the $B c l$ p polymorphism with $\pi 227$ was used in these pairwise lod score calculations since it is the most informative. As expected, given the small lod scores obtained with the sexes pooled, calculating lod scores with the sexes separated did not give any meaningful information (data not shown).

Several useful recombinants have been detected during the course of this study. One of these is subject IV. 3 in pedigree 3708 (fig 1 ) who is the result of a single recombination event separating ECB27 and $\pi 227$ from the APC gene and YN5.48; the C11p11 was not informative in this case. This indicates that loci recognised by ECB27 and $\pi 227$ are situated on the same side of the APC gene. Another recombination event, in a different family, was observed between $\pi 227$ and ECB27-APC (C11p11 and YN5.48 were uninformative) providing evidence that ECB27 is closer to $A P C$ than is $\pi 227$. An obligate recombinant in.a third pedigree between $A P C$ and $\pi 227$, together with $C 11 \mathrm{p} 11$, was also detected, placing these two markers on the same side of the gene. No recombinants between the pairs of markers C11p11-ECB27 and $A P C$-YN5.48 have been found in these families.

Significant lod scores have been obtained between $A P C$ and $\pi 227, \mathrm{C} 11 \mathrm{p} 11$ and $\mathrm{YN} 5.48$, and also between the pairs of markers $\pi 227-\mathrm{C} 11 \mathrm{p} 11, \pi 227-$ ECB27, and C11p11-ECB27. These data and the information obtained from the recombinants allow us to place the markers $\pi 227, \mathrm{C} 11 \mathrm{p} 11$, and ECB27 close together on the same side of the APC gene, which is in agreement with the findings of others. ${ }^{9}$ Also in agreement is the evidence we have in favour of YN5.48 being very close to $A P C$.

\section{Discussion}

This linkage study has used data provided from 20 unselected families ascertained since the setting up of the Northern Region Polyposis Registry in 1987. The identification of a number of recombinants together with the linkage data we have obtained enables our results to be combined with those already published to give an estimate of genetic distance for the markers used and a gene order. The combination of our own and published results for the approximate maximum lod score ( $\mathrm{Zmax}$ ) and associated recombination fractions $(\hat{\theta})$ is as follows: $\mathrm{C} 11 \mathrm{p} 11-A P C \mathrm{Z} \max =15 \cdot 33$, $\hat{\theta}=0.05^{582021} ; \pi 227-A P C \mathrm{Z} \max =19 \cdot 57, \hat{\theta}=0 \cdot 10^{1020}$;

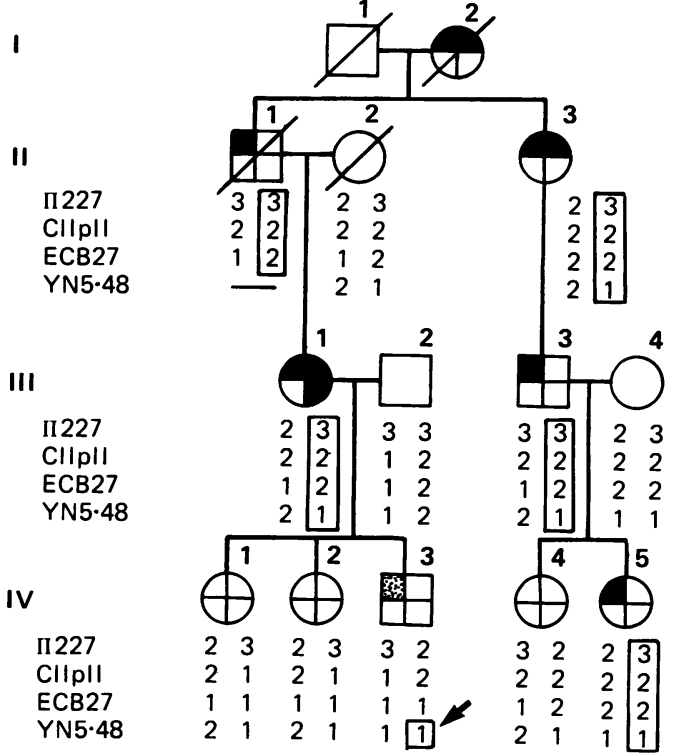

Figure 1 Part of pedigree 3708 to show evidence for a single recombination event affecting both ECB27 and $\pi 227$ but not APC-YN5.48 in IV. 3. The affected haplotype is boxed and the site of recombination is arrowed.

Screened unaffected. $\$$ P 8 CHRPEs.

Polyposis. 1 Colorectal cancer. 1 Cancer other site. В Cysts or desmoids. 
$\mathrm{ECB} 27-A P C \mathrm{Z} \max =8.98, \hat{\theta}=0 \cdot 10^{79} ; \mathrm{YN} 5.48-A P C$ $\mathrm{Zmax}=22.57, \hat{\theta}=0.05 .^{8-1021}$ Of note is the fact that the combined approximate maximum lod score for linkage of ECB27 and $A P C$ indicates that this marker is probably not as close to the gene as was originally thought. ${ }^{7}$ Taking the gene mapping data together with information from constitutional ${ }^{7}$ and somatic ${ }^{22}$ deletions, the most likely locus order is $\pi 227$ C11p11-ECB27- $A P C$-YN5.48.

Although we chose a cut off point of a total of eight or more CHRPE lesions as being indicative of gene carrier status for the purpose of this linkage analysis, in clinical practice a level of six or more is used in these families as a positive indicator. ${ }^{11}$ At risk subjects with three to five lesions can present a problem, as illustrated by fig 2 . Based on DNA typing, the results with probes YN5.48 and $\pi 227$ would suggest that subject III- 1 is unaffected, but she has four CHRPE lesions in one eye and a single lesion in the other eye. Published data ${ }^{910}$ puts YN5.48 telomeric to $A P C$, necessitating a double recombinant if III-1 is affected. This event is not impossible since the distance between these markers could be as much as $17 \mathrm{cM}$, based on a combination of CEPH data for YN5.48-C11p1 $1^{8}$ and our own data for these two markers and for YN5.48- $\pi 227$. Of course, in the, probably unlikely, scenario that YN5.48 and $\pi 227$ are both centromeric to $A P C$, only a single recombinant would be required. The remaining possibility is that she is not a gene carrier and that five CHRPEs represent the extreme of the normal range.

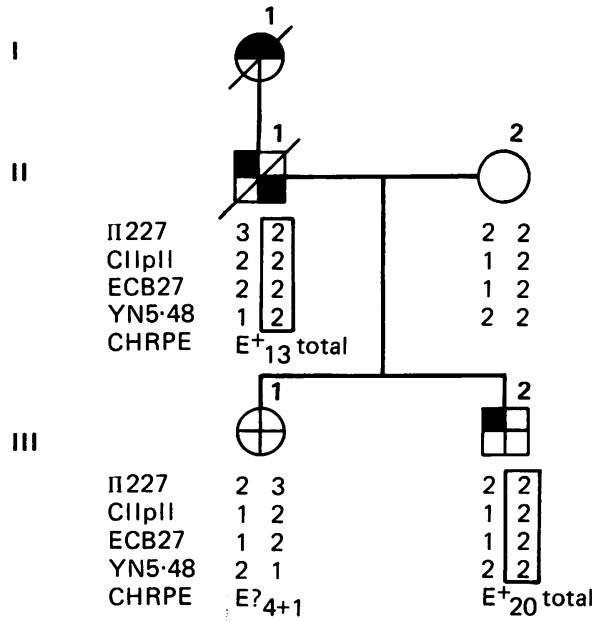

Figure 2 Part of pedigree 5515. DNA typing with flanking probes, YN5.48 and $\pi 227$, suggests that III. 1 is unaffected but she has a total of five CHRPEs necessitating the continuation of screening. Key as for figure 1 .
In all families studied the APC gene has shown linkage with at least one of the probes used. This is in agreement with all published reports that so far there is no evidence for genetic heterogeneity with respect to linkage with markers on chromosome 5 . Lod scores are now sufficiently high to allow the use of these probes in presymptomatic diagnosis.

With regard to practicalities, it is also worth noting that despite the fact that $61 \%$ of the subjects at risk were informative for at least one DNA marker, only 11 out of $72(15 \%)$ at risk subjects were in fact informative with flanking probes. This means that in most cases presymptomatic diagnosis can only be given with $90 \%$ probability at present, based on DNA typing alone. This level of risk proved acceptable to one couple requesting prenatal diagnosis where the initial request had been for sterilisation.

We, and the families who have benefitted from this study, are extremely grateful to Quest Cancer Test who provided support for $\mathrm{K}$ Tsioupra and the consumables. We are also grateful to the following people who provided probes: $W$ Bodmer, $M$ Dunlop, A-M Frischauf, Y Nakamura, and G Stewart. Pamela Chapman receives support from the Imperial Cancer Research Fund. J Attwood acknowledges support from the Medical Research Council as part of the UK Human Genome Mapping Project. We thank N E Morton for his constant help with regard to the linkage analysis and M S Povey for helpful discussion.

1 Muto T, Bussey HJR, Morson BC. The evolution of cancer of the colon and rectum. Cancer 1977;36:2251-70.

2 Bussey HJR. Familial polyposis coli. Baltimore: Johns Hopkins University Press, 1975.

3 Gardner EJ. A genetic and clinical study of intestinal polyposis, a predisposing factor for carcinoma of the colon and rectum. Am $\mathcal{F}$ Hum Genet 1951;3:167-76.

4 Bodmer WF, Bailey CJ, Bodmer J, et al. Localization of the gene for familial adenomatous polyposis on chromosome 5 . Nature 1987;328:614-9.

5 Leppert M, Dobbs M, Scambler P, et al. The gene for familial polyposis coli maps to the long arm of chromosome 5 . Science 1987;238:1411-3.

6 Meera Khan P, Tops CMJ, Broek Mvd, et al. Close linkage of a highly polymorphic marker (D5S37) to familial adenomatous polyposis (FAP) and confirmation of FAP localization on chromosome 5q21-22. Hum Genet 1988;79:183-5.

7 Varesco L, Thomas HJW, Cottrell S, et al. CpG island clones from a deletion encompassing the gene for adenomatous polyposis coli. Proc Natl Acad Sci USA 1989;86:10118-22.

8 Nakamura $Y$, Lathrop M, Leppert M, et al. Localization of the genetic defect in familial adenomatous polyposis within a small region of chromosome 5. Am f Hum Genet 1988;43:63844.

9 Dunlop MG, Nakamura Y, Wyllie AH, et al. Genetic linkage map of six polymorphic DNA markers around the gene for familial adenomatous polyposis on chromosome 5. Am $\mathfrak{F} \mathrm{Hum}$ Genet 1990;47:982-7.

10 Tops CMJ, Griffioen G, Vasen HFA, et al. Presymptomatic diagnosis of familial adenomatous polyposis by bridging DNA markers. Lancet 1989;ii:1361-3.

11 Burn J, Chapman P, Delhanty J, et al. The UK Northern Region genetic register for familial adenomatous polyposis coli: use of age of onset, congenital hypertrophy of the retinal pigment epithelium and DNA markers in risk calculations. $f$ Med Genet 1991;28:289-96. 
12 Chapman PD, Church W, Burn J, Gunn A. Congenital hypertrophy of retinal pigment epithelium; a sign of familial adenomatous polyposis. $B M F$ 1989;298:353-4.

13 Maniatis T, Fritsch EF, Sambrook J. Molecular cloning, a laboratory manual. New York: Cold Spring Harbor Laboratory, 1982.

14. Stewart GD, Bruns GAP, Wasmuth JJ. An anonymous DNA segment $(\pi 227)$ maps to the long arm of human chromosome 5 and identifies a BstXI polymorphism (D5S37). Nucleic Acids Res 1987;15:3939.

15 Feinberg AP, Vogelstein B. A technique for radiolabelling DNA restriction endonuclease fragments to high specific activity. Anal Biochem 1983;132:6-13.

16 Lathrop GM, Lalouel JM, Julier C, Ott J. Strategies for multilocus linkage analysis in humans. Proc Natl Acad Sci USA 1984;81:3443-6.

17 Attwood J, Bryant S. A computer program to make linkage analysis with LIPED and LINKAGE easier to perform and less prone to input errors. Ann Hum Genet 1988;52:259.
18 Wong Z, Wilson V, Patel I, et al. Characterisation of a panel of highly variable mini-satellites cloned from human DNA. Ann Hum Genet 1987;51:269-88.

19 Conneally PM, Edwards JK, Kidd KK, et al. Report of the committee on methods of linkage analysis and reporting. Cytogenet Cell Genet 1985;40:356-9.

20 Dunlop MG, Steel CM, Wyllie AH, et al. Linkage analysis in familial adenomatous polyposis: order of C11p11 (D5S71) and $\pi 227$ (D5S37) loci at the APC gene. Genomics 1989;5:350-3.

21 Leppert M, Burt R, Hughes JP, et al. Genetic analysis of an inherited predisposition to colon cancer in a family with a variable number of adenomatous polyps. $N$ Engl f Med 1990; 322:904-8.

22 Ashton-Rickardt PG, Dunlop MG, Nakamura Y, et al. High frequency of $A P C$ loss in sporadic colorectal carcinoma due to breaks clustered in 5q21-22. Oncogene 1989;4:1169-74. 